\title{
Miten saada ihmiset noudattamaan epidemian leviämisen estämiseen liittyviä suosituksia? Käyttäytymistieteiden anti
}

\begin{abstract}
Koronaviruksen leviämisen ehkäiseminen vaatii ihmisiä omaksumaan monia totutusta poikkeavia tapoja, kuten fyysisen etäisyyden pitämistä ja tiheää käsienpesua. Viranomaisten antamien suositusten ja ohjeiden noudattamista on mahdotonta kaikilta osin valvoa, ja osa varotoimenpiteistä saattaa jatkua hyvinkin pitkään, joten ohjeiden toimivuus on huomattavassa määrin kiinni ihmisten vapaaehtoisesta pyrkimyksestä noudattaa niitä. Psykologiassa ja sosiaalipsykologiassa on pitkä tutkimustraditio asenteisiin, motivaatioon ja käyttäytymiseen vaikuttamisen mekanismeista ja menetelmistä. Tämän artikkelin tavoitteena on 1) esitellä epidemian leviämistä ehkäisevien käyttäytymismuutosten analyysin sekä systemaattisen interventiosuunnittelun malli sekä 2) linjata käyttäytymistieteellisiin teorioihin ja tutkimusnäyttöön perustuvia konkreettisia toimintaohjeita politiikkatoimenpiteitä suunnitteleville viranomaisille. Artikkeli perustuu keskeisiä sosiaalipsykologisia teorioita kuten itsemääräämisteoriaa, sosiaalisen identiteetin teoriaa sekä tottumusteoriaa hyödyntäneisiin tutkimuksiin sekä tuoreisiin tieteellisiin artikkeleihin käyttäytymistiedon hyödyntämisestä nimenomaan sarsCoV-2-viruksen leviämisen ehkäisyssä. Käyttäytymistiedettä voidaan hyödyntää esimerkiksi suunniteltaessa havainnollistavaa ja motivoitumista tukevaa kansalaisviestintää tai uusien tottumusten luomista tukevia interventioita sekä räätälöitäessä sopivia toimenpiteitä eri väestöryhmille. Parhaimmillaan toimenpiteet aktivoivat ihmisten sosiaalista identiteettiä ja tukevat heidän omaehtoista motivaatiotaan synnyttäen vahvan omakohtaisen sitoutumisen vaadittuun käyttäytymiseen.
\end{abstract}

Avainsanat: koronavirus, sars-CoV-2, covid-19, politiikkatoimet, julkishallinto, viranomaisviestintä, käyttäytymiseen vaikuttaminen, terveyden edistäminen, ennaltaehkäisy

\section{JOHDANTO}

Koronaviruksen aiheuttama covid-19-tauti on maailmanlaajuinen uhka niin kuolleisuuden, fyysisen ja psyykkisen terveyden, talouden kuin ylipäänsä elämäntapamme näkökulmasta. Ennen kuin tauti saadaan esimerkiksi rokotteen kautta kokonaan pysäytettyä, koronaviruksen leviämisen estäminen on paljolti riippuvaista ihmisten käyttäytymisen muutoksista arjessa (WHO, 2020).
Maaliskuussa 2020 Suomen hallitus asettiuseita ihmisten välisiä fyysisiä kontakteja rajoittavia toimenpiteitä: Oppilaitosten tilat suljettiin, ja laajamittainen lähiopetus niissä keskeytettiin. Julkiset kokoontumiset rajoitettiin kymmeneen henkilöön, ja tarpeetonta oleilua yleisillä paikoilla suositeltiin välttämään. Kaupungit ja kunnat sulkivat julkisia kokoontumistiloja, monet työpaikat määräsivät työntekijänsä etätöihin. Myöhemmin rajoituksia lisättiin, ja ravintolat ja baa- 
rit määrättiin suljettavaksi ja liikkuminen $\mathrm{Uu}^{-}$ deltamaalta rajattiin. Näillä laajamittaisilla rajoitustoimenpiteillä epidemian huippua saatiin madallettua. Pakottavia rajoituksia alettiin kesällä hiljalleen keventää. Epidemian kasvun hillitsemiseksi tai jopa tukahduttamiseksi ihmisten tulisi kuitenkin noudattaa tiettyjä käyttäytymissääntöjä, vaikka niitä säädellään ja sanktioidaan vähemmän.

Käyttäytymistä ei ole helppo muuttaa: usein voimallisin, ensisijainen keino vaikuttaa ihmisten käyttäytymiseen on lainsäädännön ja asetusten kautta - vasta tämän alle jäsentyvät kaikki muut terveyden edistämisen toimenpiteet (Abraham, Kok, Schaalma \& Luszczynska, 2011). Sosiaalipsykologiset prosessit selittävät, miksi kevyet, vapaaehtoisuuteen nojaavat suositukset eivät tehoa yhtä hyvin kuin yhteiskunnallista toimintaa ja ympäristöä rajaavat toimenpiteet. Niitä on avattu myös suomalaisessa lehdistössä (Kangasniemi, 4.4.2020). Mutta tieto suositusten laiminlyömisen syistä ei vielä kerro ratkaisuista. Miten sosiaalipsykologia ja psykologia voivat auttaa ylläpitämään suositusten noudattamista, kun yhteiskunnallista sääntelyä vähennetään ja ympäristörajoituksia puretaan?

Tämän artikkelin tavoitteena on tukea toimenpiteitä, joilla lisätään koronavirusepidemiaa hillitsemään tähtäävien suositusten noudattamista kansalaisten keskuudessa. Tässä tarkoituksessa 1) esittelemme käyttäytymismuutosanalyysin ja systemaattisen interventiosuunnittelun hyötyjä käyttäytymiseen vaikuttamisen toimenpiteiden suunnittelussa ja 2) linjaamme käyttäytymistieteellisiin teorioihin ja tutkimusnäyttöön perustuvia konkreettisia toimenpide-ehdotuksia politiikkatoimia varten.

Vaikkakäyttäytymiseenvaikuttamisestaonpaljon tieteellistä tietoa, monesti poliittiset päätökset perustuvat maalaisjärkeilyyn. Esimerkiksi luottamus ihmisten rationaaliseen päätöksentekoon ohjaa monia sairauksien ennaltaehkäisyyn ja terveyden edistämiseen liittyviä toimia turhankin voimakkaasti - ajatellaan, että pelkkä tiedon tarjoaminen muuttaa ihmisten käytöstä (Marteau, Hollands \& Fletcher, 2012). Ohjeita annettaessa komenteleva ja määräilevä tyyli saattaa aiheuttaa niin vahvan vastareaktion, että ihmiset alkavat käyttäytyä ohjeita vastaan ihan vain uhmatak- seen kontrolloivaksi koettua auktoriteettia (Legault, Gutsell \& Inzlicht, 2011; Vansteenkiste, Soenens, Van Petegem \& Duriez, 2014; Weinstein, Vansteenkiste \& Paulmann, 2020), eli syntyy klassinen reaktanssi-ilmiö. Poliittiset paineet saattavat kiirehtiä päätöksentekoa ja ratkaisukeinojen valintaa, ilman että on huolellisesti analysoitu tilanne: esimerkiksi mobiilisovellus ei sovi ratkaisuksi ongelmaan kuin ongelmaan.

Toistaiseksi psykologista tai sosiaalipsykologista tutkimusta on käytetty pandemioiden ja epidemioiden yhteydessä käyttäytymisen ohjaamisessa suhteellisen vähän, eikä empiiristä evidenssiä juuri covid-19-tilanteesta vielä ole tätä kirjoitettaessa (huhti-kesäkuussa 2020). Esimerkiksi ebolan hallinnasta tehty tutkimus osoitti, että käyttäytymistieteitä käytettiin suppeasti - lähinnä riskitiedon välittämiseen - sillä toimijoilla ei ollut osaamista eikä aikaa muuhun (Czerniewska \& White, 2020). Tutkimuksia on tehty pandemiaan liittyviin käyttäytymisiin vaikuttavista tekijöistä (esim. Bish \& Michie, 2010; Gamma ym., 2017), mutta pandemian leviämistä ehkäisevien toimenpiteiden suunnitteluun käyttäytymistiedettä ei ole meidän tietojemme mukaan juurikaan käytetty, tai siitä ei ole ainakaan julkaistu tutkimuksia.

Hyödynnämme tässä artikkelissa aiempia tutkimuksia, jotka liittyvät muihin infektioihin ja terveysuhkiin sekä terveyskäyttäytymistä koskevien suositusten omaksumiseen ja noudattamiseen (mm. Drury ym., 2019; Ntoumanis ym., 2020; Oldenburg, Absetz \& Chan, 2010), ja tuoreita tieteellisiä artikkeleita käyttäytymistiedon hyödyntämisen mahdollisuuksista tämänhetkisessä pandemiassa (mm. Michie ym., 2020; Van Bavel ym., 2020; West, Michie, Rubin \& Amlôt, 2020). Tukea saaneista teorioista voi johtaa yleisiä periaatteita, jotka voivat auttaa koronaan liittyvien toimenpiteiden suunnittelussa. Vaikka varmuutta niiden toimivuudesta tässä kontekstissa ei ole, tarjoavat ne akuutissa tilanteessa kuitenkin vahvempaan evidenssiin perustuvaa ohjeistusta kuin pelkkä arkijärkeily.

Artikkelin rakenne on seuraava: Ensin esittelemme käyttäytymistieteellisen tilanneanalyysin ja systemaattisten viitekehysten käytön antia toimenpiteiden suunnittelussa. Tässä osassa esitellään suunnittelun neljä päätehtävää sekä 
suunnittelua koskevia läpileikkaavia periaatteita. Systemaattisen prosessin viitekehys ja siihen sisältyvät konkreettiset käsitteelliset työkalut ja välineet auttavat analysoimaan ja diagnosoimaan käyttäytymismuutosongelman ja kontekstin sekä ohjaavat järjestelmällisesti harkitsemaan kaikkia olennaisia seikkoja suunnitteluprosessin aikana. Siten ne voivat jo yksistään merkittävästi hyödyttää toimenpiteiden suunnittelua ja tehostaa niiden vaikuttavuutta.

Käsillä olevassa pandemiassa voi toteuttaa monenlaisia relevantteja käyttäytymisen muutosta tukevia toimenpiteitä. Esimerkiksi miten ihmisille voidaan opettaa automaattisten rutiinien muodostamisen keinoja käsihygienian lisäämiseksi? Miten kaupoissa tai muissa julkisissa tiloissa saadaan ihmiset pitämään kahden metrin turvaväli? Miten terveydenhuoltojärjestelmä voi saada oireiset tai oireettomat ihmiset käymään testeissä? Kuinka saada mahdollisimman moni aikuinen lataamaan käyttöönsä sovellus epidemian hillitsemistä varten? Artikkelin toisessa osassa käydään läpi konkreettisia käyttäytymistieteisiin perustuvia toimenpide-ehdotuksia covid-19-pandemiatilanteeseen. Tässä yhteydessä hahmotellaan myös toimenpiteiden erilaisia toteutustapoja ja kaksi kuvitteellista esimerkkiä mini-interventioista. Artikkelin lopussa käsittelemme empiirisen näytön astetta pureutuen erityisesti siihen, miten tietoa koskevaa epävarmuutta tulisi ja voisi huomioida päätöksenteossa.

\section{OSA 1. KÄYTTÄYTYMISTIETEELLISEN ANALYYSIN JA VIITEKEHYSTEN ANTI TOIMENPITEIDEN SUUNNITTELUSSA}

Tiedämme, että ihmisen käyttäytymiseen vaikuttavat monet tekijät - kognitiiviset, affektiiviset, sosiaaliset sekä ympäristötekijät. Mutta miten valjastaa ja organisoida nämä tekijät ja prosessit optimaalisella tavalla halutun käyttäytymisen tukemiseksi?

Vaikuttamiskeinojen käytön suunnittelussa on hyödyllistä jäsentää ajattelua ja toimenpiteiden suunnittelua selkeän viitekehyksen avulla, joka opastaa läpi olennaisten osatehtävien ja siten strukturoi suunnitteluprosessia (Hankonen \& Hardeman, 2020).
Ihannetilanteessa interventioiden suunnittelu perustuu vahvaan kohderyhmän, muutettavien käyttäytymisten, kontekstin, muutosmekanismien ja muutoskeinojen ymmärrykseen (Bartholomew Eldredge, Markham, Ruiter, Kok \& Parcel, 2016; Hankonen \& Hardeman, 2020). Monet interventiokehittämisen viitekehykset (Hankonen \& Hardeman, 2020; O'Cathain ym., 2019) ohjaavat kehittäjiä systemaattiseen lähestymistapaan, jonka vaiheet perustuvat seuraaviin avaintehtäviin: 1) tunnista ja analysoi kohdeongelma mahdollisimman tarkasti määriteltyinä käyttäytymisinä, 2) valitse interventiomekanismit, sisältö ja jakelutapa, ja suunnittele logiikkamalli tai ohjelmateoria, 3) kehitä materiaalit tai prototyyppi (esim. sovellus), ja 4) testaa ja pilotoi interventiota ja sen osia iteratiivisesti käytännössä, ja optimoi sisältöjä palautteen ja havaintojen mukaan. Käymme nämä tehtävät seuraavassa läpi pääpiirteittäin. Varsinaisen suunnittelun jälkeen vuorossa ovat intervention vaikuttavuuden ja prosessien arviointi ja laajamittainen toimeenpano, mutta näitä ei käsitellä tässä artikkelissa. Käyttäytymistieteellisten interventioiden suunnittelusta ja arvioinnista voi lukea suomeksi tarkemmin muualta (esim. Hankonen, 2012, 2017; Linnansaari \& Hankonen, 2019).

Kulttuurinen yhteensopivuus, interventiouskollisuus (engl. fidelity), toteutuskelpoisuus ja hyväksyttävyys ovat seikkoja, joita tulisi pohtia jokaisessa tehtävässä (Hankonen \& Hardeman, 2020). Lisäksi kannattaa huomata, että interventiokehittämisen tehtävät voi toteuttaa kohtuullisen nopeasti tai perinpohjaisemmin - riippuen aikavaatimuksista ja käytössä olevista resursseista (Hankonen \& Hardeman, 2020).

\section{Tehtävä 1. Analysoi kohdeongelma ja käyttäytyminen}

Ongelma - koronaviruksen leviäminen ja sen ehkäiseminen - tulee muotoilla käyttäytymisinä. Koronaviruspandemian hillitsemisen kannalta olennaista on yksilön suojautumiskäyttäytyminen eli yksilön omaan ja muiden suojeluun tähtäävät toimet ja fyysisen etäisyyden pitäminen toisiin ihmisiin.

Epidemioihin liittyvissä käyttäytymismuutosinterventioissa kohdekäyttäytymisen valinnassa ollaan sen tutkimusnäytön varassa, jota lääketie- 
teestä ja epidemiologiasta saadaan: mitkä käyttäytymismuodot ovat sellaisia, että ne ovat epidemian torjunnassa tärkeitä? Tähän ei käyttäytymistieteellinen tutkimus vastaa. The Independent Scientific Advisory Group for Emergencies (SAGE) -ryhmän (2020) raportin mukaan hyvää näyttöä on sosiaalisen (fyysisen) etäisyyden pitämisen ja käsien puhdistamisen vaikuttavuudesta. Vähemmän näyttöä on olemassa nenäliinojen oikean käytön, kasvojen koskettamisen välttämisen, pintojen desinfioimisen ja kasvosuojusten käyttämisen osalta.

Kohdekäyttäytyminen sekä siihen vaikuttavat tekijät (esteet ja mahdollistajat) eritellään kussakin kohdeväestössä ja kontekstissaan, esimerkiksi yksilö- ja ympäristötasoihin eritellen. Tällainen systemaattinen analyysi auttaa valitsemaan sopivimman teorian kuhunkin spesifiin tilanteeseen, ja voidaan valita kuhunkin parhaiten sopivat keinot ja arvioidaan keinojen potentiaali julkilausuttuja kriteerejä vasten.

\section{Alustava ohjelmateoria tai logiikkamalli}

Teoriaan perustuvat interventiot ovat keskimäärin vaikuttavampia (esim. Webb, Joseph, Yardley \& Michie, 2010), joskin tulee huomioida myös teorian soveltamisen laadukkuus (Hagger \& Weed, 2019; Michie \& Prestwich, 2010). Kuitenkin aivan kaikki vaikuttamisyritykset perustuvat vähintään arkijärkiseen, implisiittiseen teoriaan siitä, miten vaikutus saataisiin aikaan. Interventioita suunniteltaessa ja arvioitaessa onkin tarkoituksenmukaista julkilausutusti sanoa ääneen oletukset vaikuttamisen mekanismeista, joiden mukaan interventio on suunniteltu. Tämän voi ilmaista intervention ohjelmateoriana, jonka voi muotoilla myös visuaalisesti niin sanotun logiikkamallin muodossa (Hankonen \& Hardeman, 2020; Linnansaari \& Hankonen, 2019). Kullekin interventiolle spesifin ohjelmateorian rakentamisessa voidaan hyödyntää useita psykologiatieteen formaaleja teorioita.

Ihmisen käyttäytymiseen vaikuttavat monet seikat - hetkelliset mielihalut, pitkäjänteiset suunnitelmat ja periaatteet, odotus siitä miten muut käyttäytyvät ja miten ohjeet ja säännöt on omaksuttu ja koettu. Yksi tapa jäsentää käyttäytymiseen vaikuttavia tekijöitä on jakaa ne kolmeen päälohkoon: kykyihin, ympäristön suomiin mahdollisuuksiin ja motivaatioon (Capability, Motivation, Opportunity - Behaviour (COM-B) -malli). Tutkimusnäytön mukaan paras vaikuttavuus käyttäytymismuutokseen on interventioilla, jotka toimivat samanaikaisesti ja useilla eri tasoilla ja jotka ovat pitkäkestoisia ja intensiivisiä (kroonisten tautien yhteydessä mm. Oldenburg ym., 2010).

Kuten edellä todettiin, suojautumiskäyttäytyminen koostuu monista eri käyttäytymisistä, joilla voi olla osin samoja, osin eri mahdollistajia ja esteitä. Taulukko 1 esittelee COM-B-mallia esimerkinomaisella "diagnoosilla" eri käyttäytymismuodoista, jotka ovat olennaisia suojauduttaessa koronavirukselta.

Kohdekäyttäytymisiä ja -ryhmiä tulisi myös pohtia osana käyttäytymis- ja ekologisia systeemejä, ja lopuksi tulisi tunnistaa kaikki relevantit ryhmät ja kontekstit interventiolle. Esimerkiksi toukokuun 2020 alussa havaittiin, että siinä missä valtaosa suomalaisista lähti noudattamaan rajoituksia keväällä halukkaasti, niiden purkamisen yhteydessä kansa alkoi jakautua selvemmin: noin kolmannes aikoi omaehtoisesti jatkaa esimerkiksi muista etäällä pysymistä, kun taas noin kolmannes aikoi palata lähes tavalliseen elämään (Ylen kysely). Mikäli epidemiologisten mallien osalta on syytä olettaa, että normaaliin arkeen palaavia on liian iso määrä tartuttavuusluvun pitämiseksi alhaalla, toimenpiteitä tulisi kohdistaa erityisesti heihin.

Kysymyksiä,joihin tässä suunnittelun vaiheessa vastataan:

- Keiden kaikkien asiantuntemusta ja käytännön kontekstin tuntemusta suunnitteluryhmään tarvitaan? Miten kohderyhmän edustajia voitaisiin osallistaa suunnittelussa? Mitä kohderyhmä tarvitsee?

- Mikä on ongelma, ja mitkä ovat siihen liittyvät käyttäytymiset? Millaiset tekijät ja prosessit siihen vaikuttavat ja osana millaisia systeemejä?

- Keiden täytyy muuttaa toimintaansa, miten, missä ja milloin? Jos ympäristöjä tarvitsee muuttaa varsinaisen kohderyhmän toiminnan muuttamiseksi, ketkä kontrolloivat näitä ympäristöjä ja miten heidän käyttäytymistään muutetaan? - Miten kohderyhmän ihmiset itse mieltävät kohdeongelman ja kohdekäyttäytymisen? Millai- 


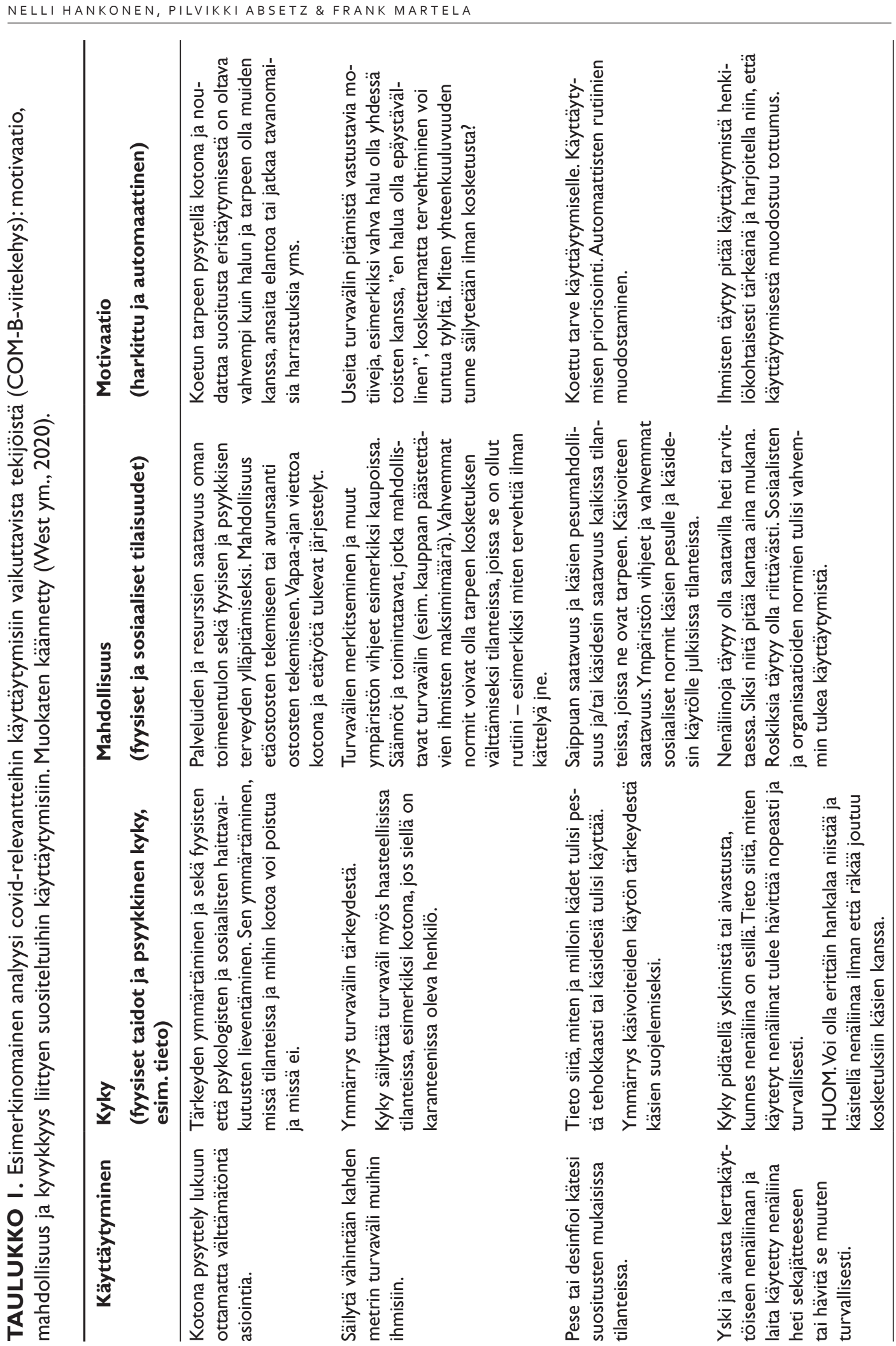

320 PSYKOLOGIA 


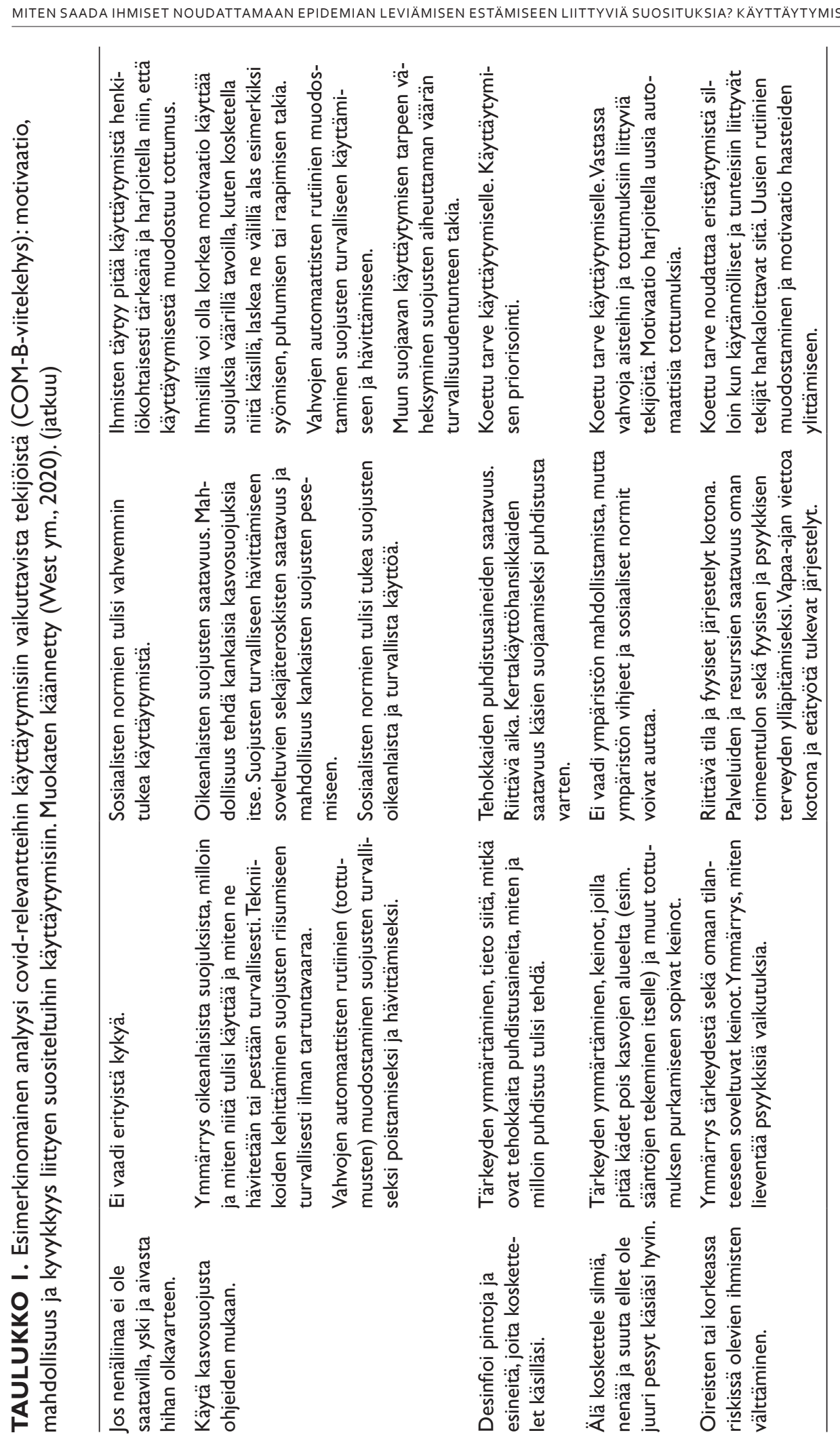


sia esteitä ja mahdollistavia tekijöitä he mieltävät käyttäytymiselle olevan?

\section{Tehtävä 2. Valitse interventiokomponentit ja intervention oletetut mekanismit}

Tässä vaiheessa arvioidaan, mitkä ovat halutun muutoksen kannalta tärkeimmät mekanismit sekä minkälaisten tekijöiden kautta ja millä keinoilla niihin voi parhaiten vaikuttaa. On oletettavaa, että keinojen tehokkuus vaihtelee eri käyttäytymisten lisäksi sen mukaan, mihin mahdollistajiin ja esteisiin keinoilla pyritään vaikuttamaan.

COM-B-malli on hyvin yleisluontoinen viitekehys, joka kartoittaa käyttäytymisen pääasiallisia vaikuttimia. Tarkempia, yksityiskohtaisia teorioita voidaan käyttää apuna sen jälkeen, kun tunnistetaan keskeisimmät vaikuttamisen reitit.

Yleensä tarjolla on useita eri mahdollisuuksia vaihtoehtoisiksi vaikuttamisen keinoiksi,ja niiden potentiaalia kannattaa arvioidaeksplisiittisten kriteerien avulla. Behaviour Change Wheel (BCW) -viitekehys auttaa osoittamaan keinoja COM-Bmallin eri osa-alueilla. Viitekehykseen sisältyvät niin sanotut APEASE-kriteerit (Michie, Atkins \& West, 2014; Michie ym., 2020), jotka voivat olla oiva tukipuu vaikuttamisen eri keinojen hyötyjä, haittoja ja kokonaispotentiaalia arvioitaessa: onko keino hyväksyttävä (Acceptability), käytännössä toteutettavissa (Practicability), vaikuttava
(Effectiveness), kustannustehokas (Affordability) ja ovatko sen sivuvaikutukset pääosin myönteisiä (Side-effects and safety) ja tasapuolisia eri väestöryhmissä (Equity) (Taulukko 2).

Huomionarvoista on, että keinoja voivat käyttää yhteiskunnan monet eri toimijat, monilla eri tasoilla, lähtien viestinnällisistä keinoista valtionjohdon puheissa, aina organisaatioiden toimintaan. Keinoja voidaan sisällyttää koulutuksena, viestintänä, suostutteluna, kannustimina, mahdollistamisena ja pakottavampina toimenpiteinä.

Kysymyksiä, joihin tässä vaiheessa vastataan:

- Mitä ideoita mahdollisista vaikutuskeinoista on? Millä niistä on eniten potentiaalia (kriteerien ja rajoitteiden valossa)?

- Miten ymmärrys ongelmasta ja käyttäytymisestä tarkentuu?

- Miten käyttäytymiseen vaikuttamisen periaatteet operationalisoidaan käytännön toiminnaksi?

- Mitä kohderyhmän ihmiset itse ajattelevat näistä kysymyksistä ja suunnitelmista?

- Mikä on lopullinen, täsmennetty ohjelmateoria?

\section{Tehtävä 3. Materiaalien suunnittelu}

Teoreettiset vaikuttamisen periaatteet materialisoituvat internetsivuina, sovelluksina, lehtisinä, televisiopuheina, meemeinä, somevaikuttajan

TAULUKKO 2. APEASE-kriteerit potentiaalisten interventiolähestymistapojen tai -komponenttien arvioimiseksi ja priorisoimiseksi (Michie, Atkins \&West, 20I4; Michie ym., 2020).

\begin{tabular}{ll}
\hline Kriteeri & Missä määrin keino... \\
\hline Hyväksyttävyys & $\begin{array}{l}\text { on hyväksyttävä kaikille osapuolille (esim. poliitikot, toteuttajat, koh- } \\
\text { deryhmä, kansalaiset)? }\end{array}$ \\
Toteutettavuus käytännössä & $\begin{array}{l}\text { voidaan toteuttaa tarkoitetulla tavalla, tarkoitetussa mittakaavassa ja } \\
\text { tarkoitetussa kontekstissa? }\end{array}$ \\
Vaikuttavuus & saa aikaan haluttuja lopputuloksia kohderyhmässä? \\
Kustannustehokkuus & voidaan maksaa aiotulla budjetilla? \\
Spill-over-vaikutukset & $\begin{array}{l}\text { saa aikaan sivuvaikutuksia - joko positiivisia tai negatiivisia? } \\
\text { Tasa-arvo }\end{array}$ \\
$\begin{array}{l}\text { todennäköisesti lisää yhteiskunnallista epätasa-arvoa (esim. ovatko } \\
\text { hyötyvaikutukset todennäköisiä etupäässä sosioekonomisesti hyvä- } \\
\text { osaisilla)? }\end{array}$ \\
\hline
\end{tabular}


postauksina tai blogeina, koulussa pidettävinä oppitunteina materiaaleineen, videoina ja niin edelleen. Konkretian suunnittelussa kannattaa olla tarkkana.Jos materiaalien suunnittelussa käytetään ulkopuolisia tahoja kuten viestinnän ammattilaisia, heidän tulee ymmärtää ohjelmateoria eli käyttäytymisen vaikuttamisen prosessit ja mekanismit. Siksi ohjelmateorian julkilausumiseen ja selkeyteen kannattaa panostaa suunnitteludokumenteissa (Bartholomew Eldredge ym., 2016).

Kysymyksiä, joihin tässä vaiheessa vastataan:

- Miten voimme hyödyntää esimerkiksi graafisen suunnittelun tai muotoilun osaajia materiaalien tuotannossa? Voimmeko visualisoida tietoa havainnollisuuden lisäämiseksi?

- Mitä käyttäytymistieteellisiä periaatteita materiaalista pitää välittyä? Minkä teoreettisten periaatteiden ei tule vesittyä tekstimuotoiluja tehdessä?

- Mille ymmärrystasolle materiaali tulee sovittaa (esim. selkokielisyys)?

\section{Tehtävä 4. Esitestaus}

"Nojatuolisuunnittelu" eli käyttäytymistieteellisten periaatteiden hyödyntäminen toimenpiteiden suunnitteluksi ilman käytännön testaamista ei toimi, siksi lähes kaikki viitekehykset suosittelevat kokeilemaan ideoita käytännössä (Hankonen \& Hardeman, 2020; O'Cathain ym., 2019). Ideoita kannattaa pienimuotoisestikin testata varsinaisella kohderyhmällä (esim. koulun oppilailla) tai heille sen jakelevilla tahoilla (esim. opettajilla tai terveydenhoitajilla). Esitestauksen voi tehdä pikatestauksena vaikkapa internetvälitteisissä fokusryhmissä tai varsinkin laajemman intervention kohdalla formaalimpana pilottina.

Tämän vaiheen kysymyksiä:

- Ymmärtävätkö kohderyhmän edustajat esimerkiksi materiaalien viestit kuten on tarkoitettu, vai tuleeko tahattomia väärinymmärryksiä?

- Millaisia reaktioita interventio tuntuu herättävän tai synnyttävän?

- Vaikkei esitestauksessa käytettäisi riittävän isoa otosta vaikutusten luotettavaa arviointia ajatellen, voidaanko kuitenkin päätellä jotain mahdollisista vaikutuksista tai niiden myöhempään arviointiin sopivista mittareista?

- Näyttäisikö esitestauksen perusteella intervention laajamittainen jakelu tarkoitetusti (uskol- lisesti) onnistuvan?

- Koetaanko toimenpiteet hyväksyttäviksi (miellyttäviksi, eettisiksi, ymmärrettäviksi, tehokkaiksi) (Sekhon, Cartwright \& Francis, 2017)? Tuottaako interventioon osallistuminen kohtuuttomia vaihtoehtoiskustannuksia tai vaivaa (Sekhon ym., 2017)?

- Kannattaako kehittämistä jatkaa ja interventiota levittää laajemmin, vai tarvitseeko prosessin aiempiin tehtäviin palata intervention optimoimiseksi, jos esitestauksessa löydettiin merkittäviä ongelmia perusasioissa?

\section{Interventiosuunnittelun avainperiaatteina iteratiivisuus ja osallistaminen}

Edellä kuvatut neljä vaihetta tai tehtävää voidaan käydä läpi - resursseista, kiireestä ja osaamisesta riippuen - joko muutamassa tunnissa tai usean vuoden aikana. Pääasia on tulla tietoiseksi ja edes lyhyesti harkita erilaisia keskeisiä seikkoja, jotka voivat vaikuttaa ratkaisevasti valittujen toimenpiteiden toteutuskelpoisuuteen ja vaikuttavuuteen: lyhytkin systemaattinen prosessi on parempi kuin harkitsematon toimintaan syöksyminen.

Tehtäviä voi suorittaa iteratiivisesti, eli esitestauksen jälkeen saattaa joutua palaamaan kohdekäyttäytymisen (tehtävä 1) tai vaikuttamiskeinojen (tehtävä 2) mietintään ja määrittelyyn. Prosessi ei ole lineaarinen, vaan sekava ja suttuinen, kuten monimutkaisen maailman ongelmien ratkaisu käytännössä aina - mutta selkeät tehtävät helpottavat orientoitumista (Hankonen \& Hardeman, 2020).

Kehittämistiimissä kannattaa hyödyntää kohderyhmän edustajia ja muiden keskeisten sidosryhmien edustajia mahdollisuuksien mukaan joka vaiheessa ja joka tehtävässä. Kuten edellä todettiin, kaikissa keinoissa haittavaikutukset tulee minimoida ja on tärkeä myös ajatella vaihtoehtoiskustannuksia. Näiden harkinnassa tarvitaan yhteistyötä.

Päätään on nostamassa myös kompleksisten järjestelmien lähestymistapa käyttäytymismuutosprosessien ymmärtämisessä (Heino, Knittle, Noone, Hasselman \& Hankonen, 2020) ja interventioiden suunnittelemisessa (Hankonen \& Hardeman, 2020). Vaikka monissa teorioissa muutokseen liittyvät prosessit oletetaan dynaa- 
misiksi ja vuorovaikutteisiksi, interventioiden logiikkamalleissa tai prosessiarvioinneissa näitä tyypillisesti typistetään liialti.

Seuraavaksi siirrymme artikkelin toiseen tehtävään - millaisia toimia meneillään olevan pandemian hillitsemiseksi voitaisiin suositella?

\section{OSA 2. KÄYTTÄYTYMISTIETEISIIN PERUSTUVIA TOIMENPIDE-EHDOTUKSIA COVID-19- PANDEMIATILANTEESEEN}

Miten käyttäytymistieteet voivat opastaa valittaessa toimenpiteitä suositusten noudattamisen lisäämiseksi väestön keskuudessa? Kaiken kaikkiaan käyttäytymismuutoksen kannalta relevantteja teorioita on valtava määrä: eräs katsaus on löytänyt niitä 83 (Michie, West, Campbell, Brown \& Gainforth, 2014) ja toinen 100 (Kwasnicka, Dombrowski, White \& Sniehotta, 2016). Tuore ajantasainen teos, The handbook of behavior change (Hagger, Cameron, Hamilton, Hankonen \& Lintunen, 2020), esittelee kymmeniä tukea saaneita teorioita erityisesti käyttäytymismuutoksen kontekstissa. Tämän katsauksen puitteissa on ollut tarkoituksenmukaista listata esimerkinomaisesti joitain teorioita eri suositusten yhteyteen - minkään yksittäisen teorian puuttuminen tästä katsauksesta ei siis tarkoita, etteikö teoriasta voisi olla hyötyä akuutin pandemiatilanteen vaatimien toimenpiteiden suunnittelussa. Suosittelemme tutustumaan teorioihin ja niiden tarkempiin oletuksiin ja ehtoihin tarkemmin muualla. Tilan rajallisuuden vuoksi keskitymme tässä yksilöiden käyttäytymisen muuttamiseen. Yhteisö-, organisaatio- ja systeemitason interventioista on tuoreita koonteja muualla (Ruiter, Crutzen, de Leeuw \& Kok, 2020).

Hyödynnämme tässä osassa paitsi viime aikoina julkaistuja koronakriisiin liittyviä psykologisia ja käyttäytymistieteellisiä artikkeleita, myös laajasti muuta teoreettista ja empiiristä kirjallisuutta. Olemme listanneet joukon yleisiä periaatteita (Taulukko 3), jotka on teoriassa esitetty ja empiirisesti joissain konteksteissa testattu. Ehdotettujen toimenpiteiden empiiristä näyttöä ei ole käsitelty systemaattisesti, ja ne tulisi nähdä alustavana listauksena mahdollisesti hyödyllisistä toimenpiteistä, joiden lopullinen vaikuttavuuden arviointi odottaa vielä tulevaa tutkimusta. Kunkin toimenpiteen yhteydessä on kuitenkin muutama lähdeviite, joista voi tarkistaa minkä tutkimusnäytön tai teorian pohjalta toimenpiteen voisi olettaa olevan vaikuttava, kun pyrkimyksenä on edistää koronaan liittyvien suositusten noudattamista väestön keskuudessa.

Hiljattain on ilmestynyt useita koontiartikkeleita tämänhetkisen pandemian kannalta olennaisista käyttäytymis- ja yhteiskuntatieteellisistä teoreettisista näkökohdista (esim. Michie ym., 2020; Van Bavel ym., 2020; West ym., 2020). Joukko tutkijoita (Bonell ym., 2020) on koonnut Ison-Britannian hallitukselle etäisyyden pitämistä ("social distancing") edistävien kampanjoiden suunnitteluun listan teoriaan perustuvia periaatteita. He suosittelivat seuraavia viestejä: 1 ) selkeät ja tarkat ohjeet (tieto on välttämätöntä mutta ei riittävää käyttäytymisen muuttamiseksi), 2) "suojellaan toisiamme" -viestit, 3) "toimitaan yhdessä" -viestit, 4) "me toimimme näin" -viestit (deskriptiivinen ja injunktiivinen normi), 5) suunnitelman tekemistä ja sen säännöllistä arviointia tukevia materiaaleja ja 6) mahdollistamista tukevia viestejä (kerrotaan samalla myös konkreettisesta avusta tulonsiirtojen, vanhemmuuden tuen ja muun muutosta helpottavan toiminnan tuen osalta, erityisesti vähäosaisille). Tutkijaryhmä kehotti välttämään 1) toisiin ihmisiin kytkeytyvän inhon ja pelon tunteiden herättämistä (vaikka omien käsien pesemiseen näiden tunteiden on havaittu vaikuttavan) ja 2) autoritaarista viestintää (pakottaminen ei välttämättä toimi pitkällä aikavälillä, ja kansalaistottelemattomuus voi seurata varsinkin epäoikeudenmukaiseksi koettuja ja epätasaarvoisia lopputulemia tuottaneita sulkuja).

\section{Toimenpiteiden toteutuksen tapoja}

Taulukon 3 toimenpiteet/periaatteet on yksinkertaisuuden vuoksi listattu yksilötason esimerkein. Toimenpiteitä/periaatteita voi kuitenkin soveltaa monin eri tavoin.

\section{Ryhmän voiman valjastaminen käyttäytymisen muutokseen}

Meta-analyysinäytön mukaan yhdessä ystävän, puolison tai ryhmän kanssa tehdyt tavoitteet johtavat todennäköisemmin tavoitteen saavuttami- 


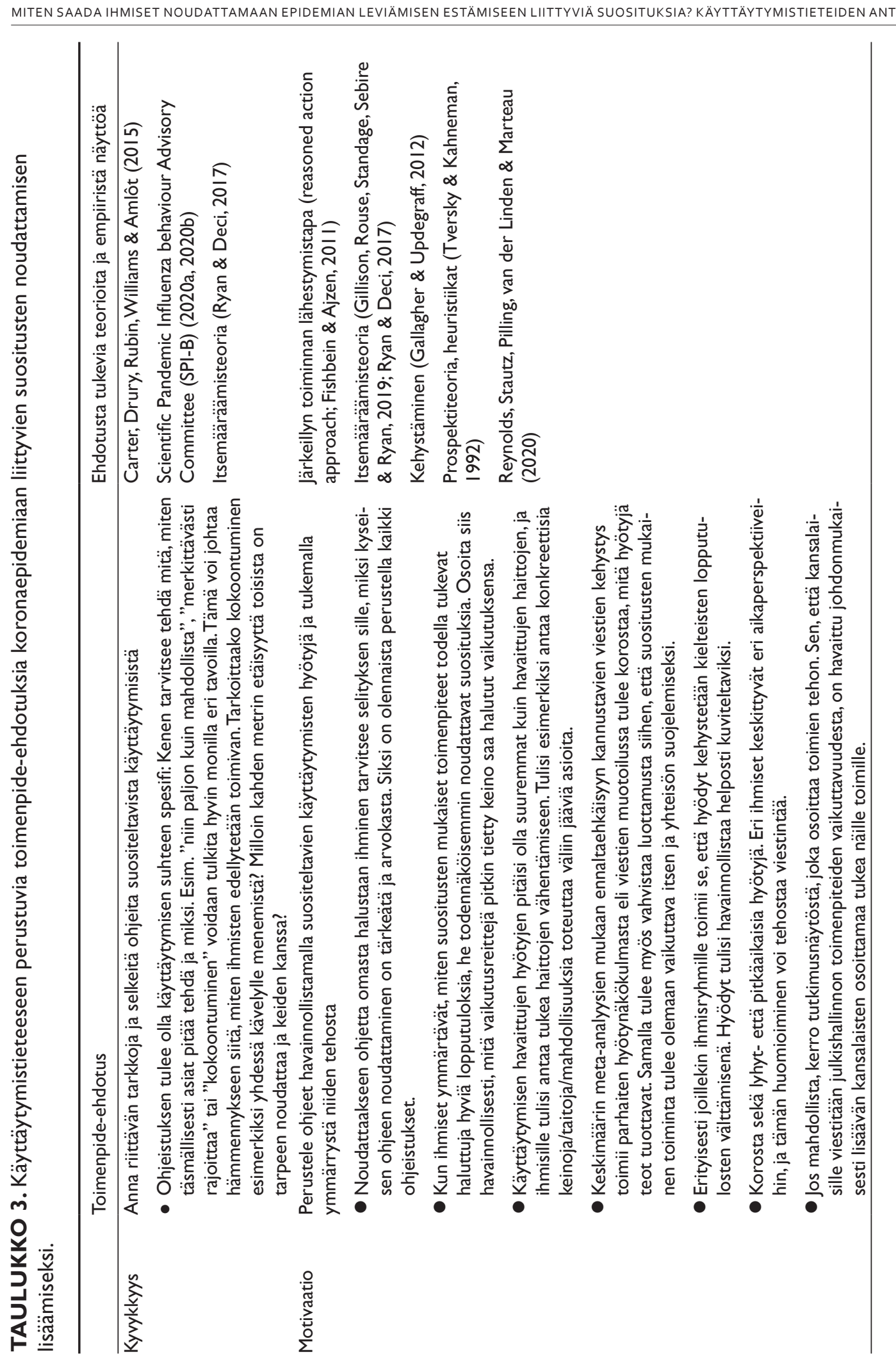




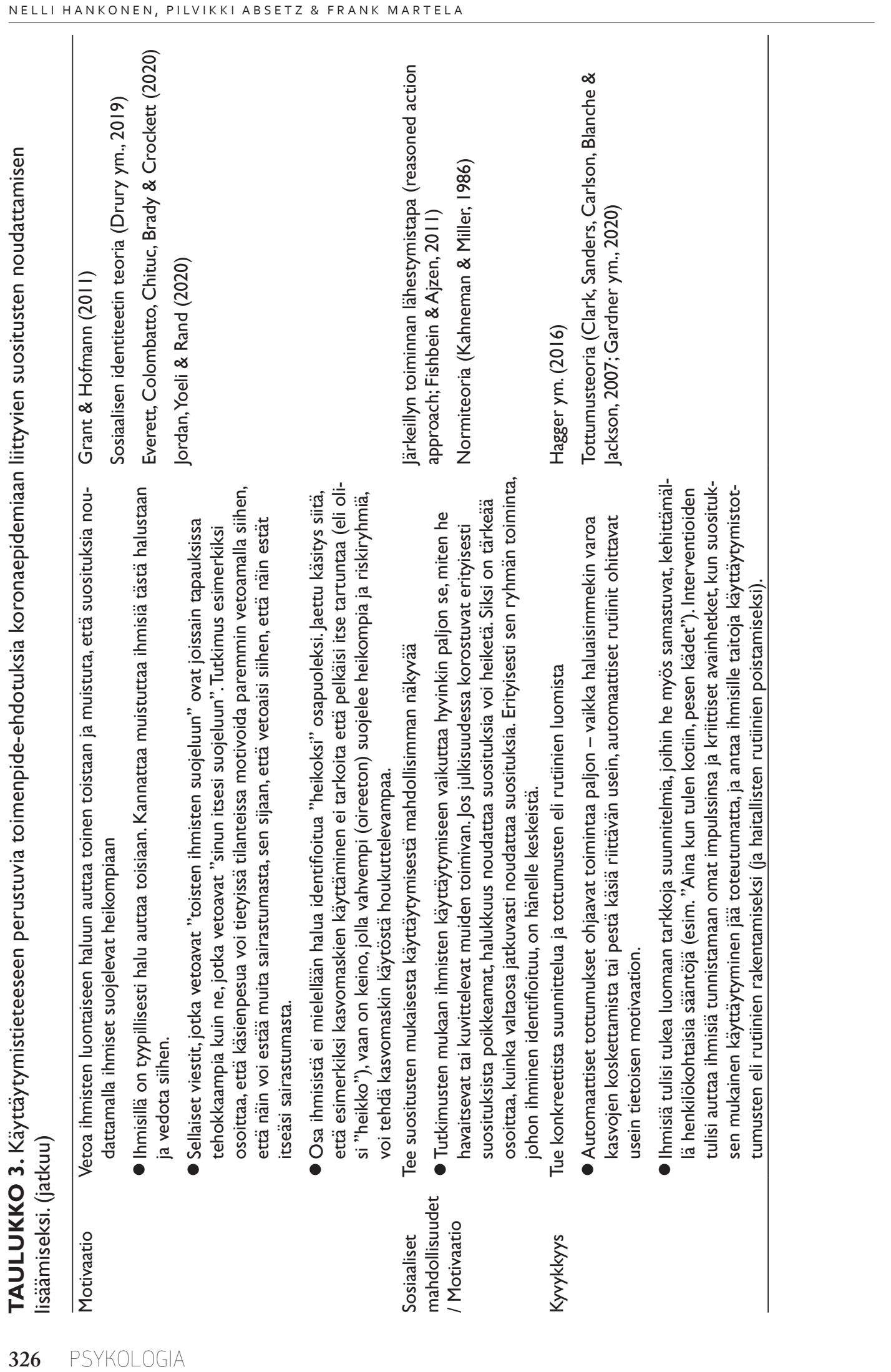




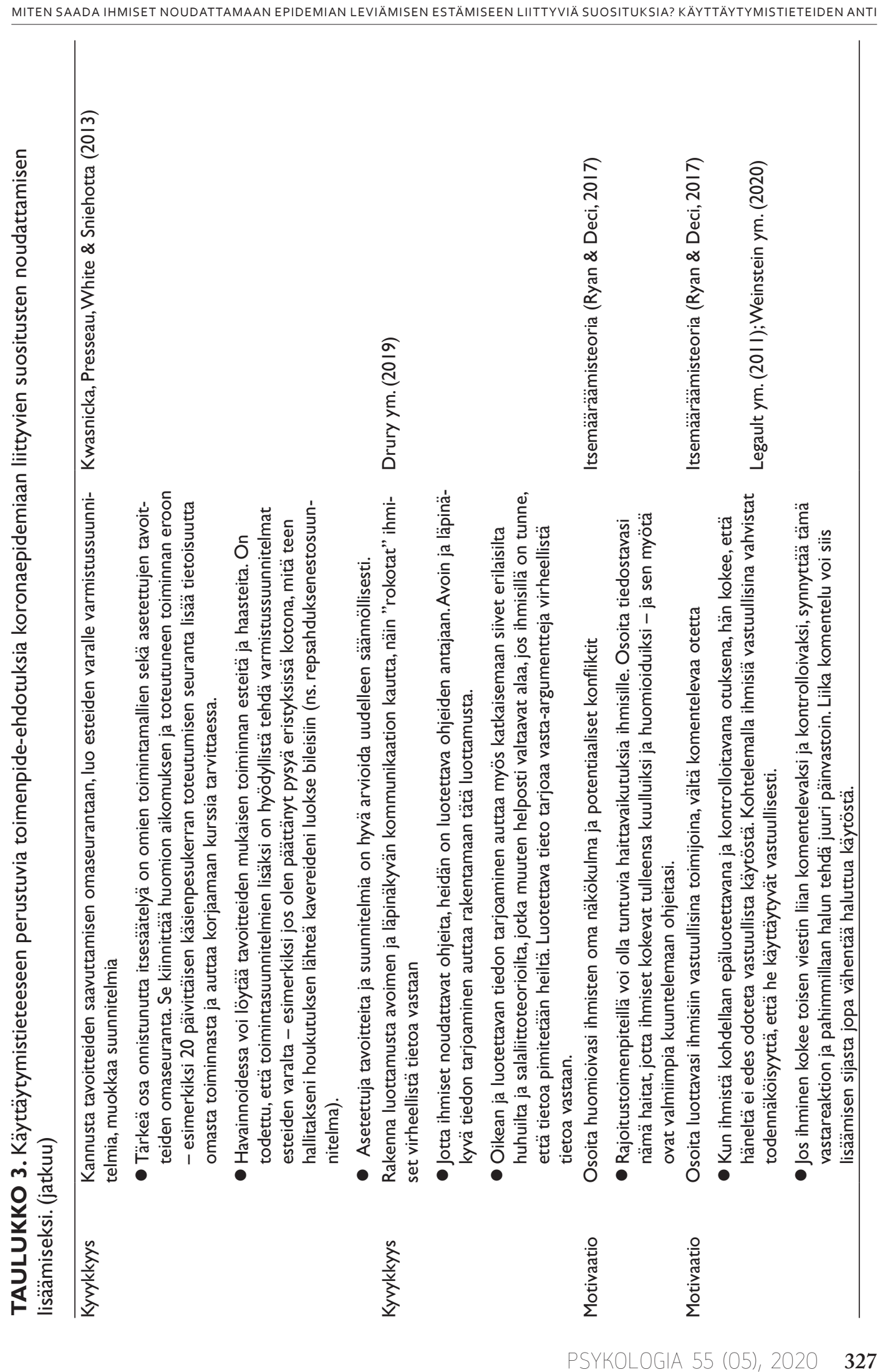




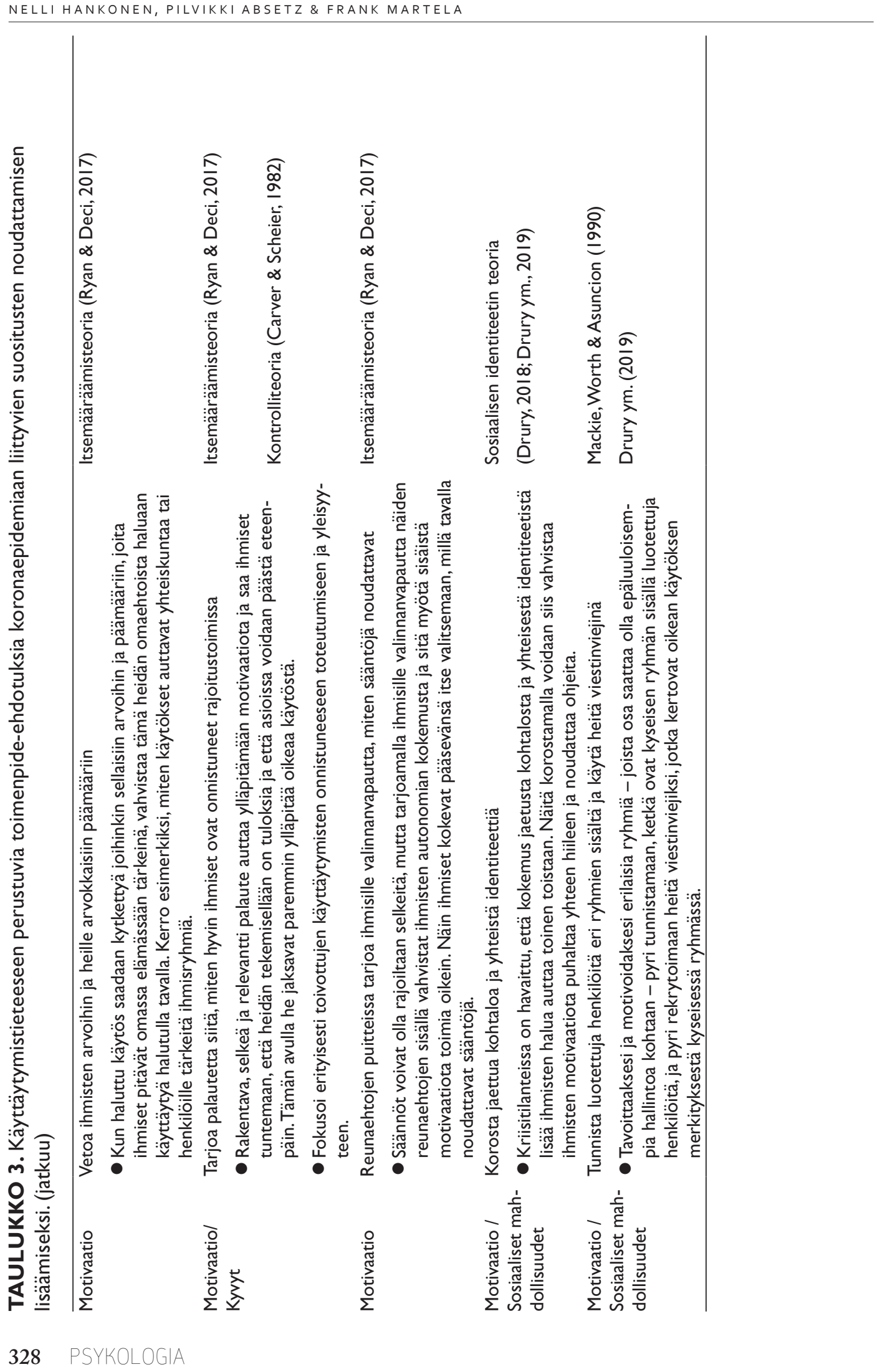




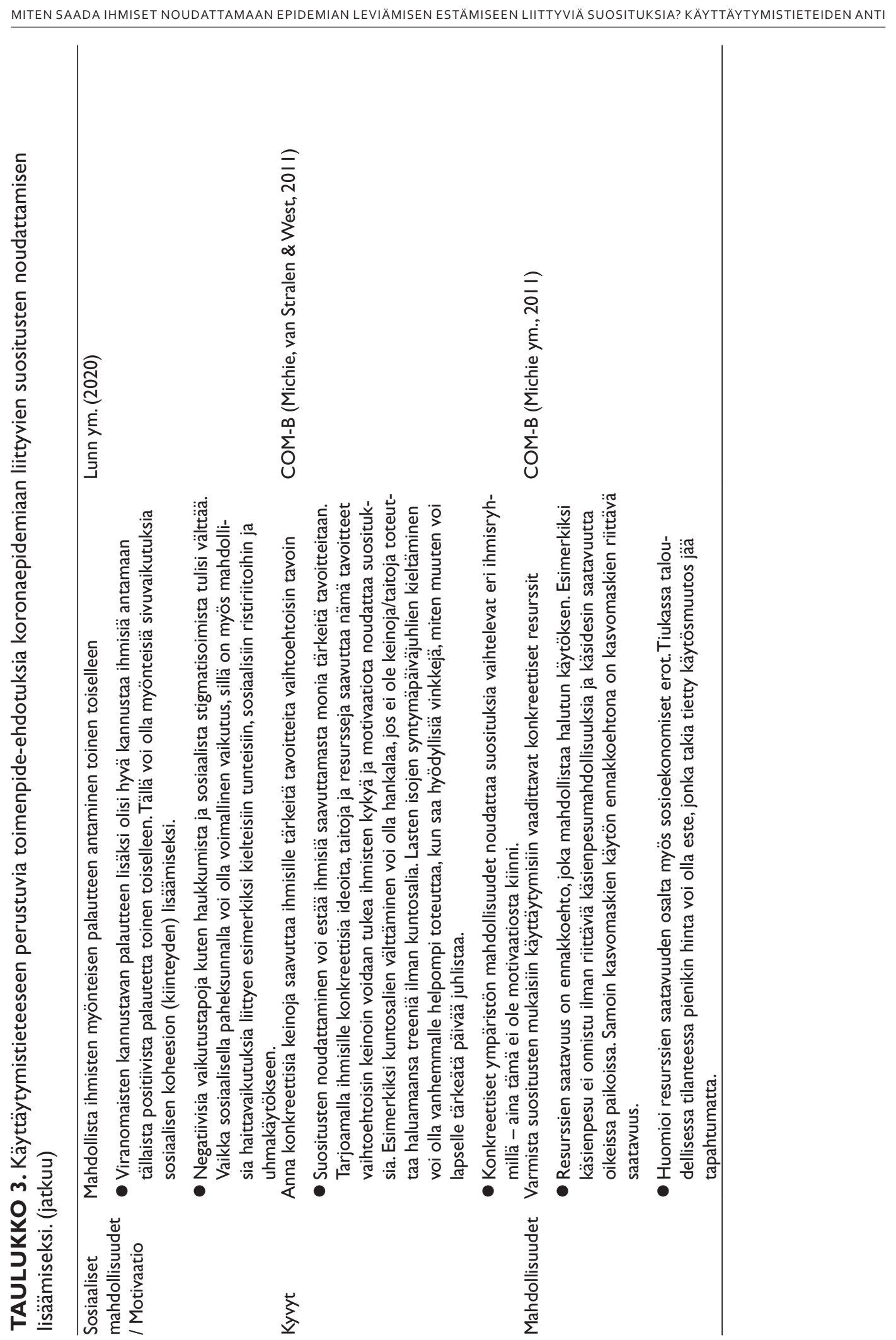




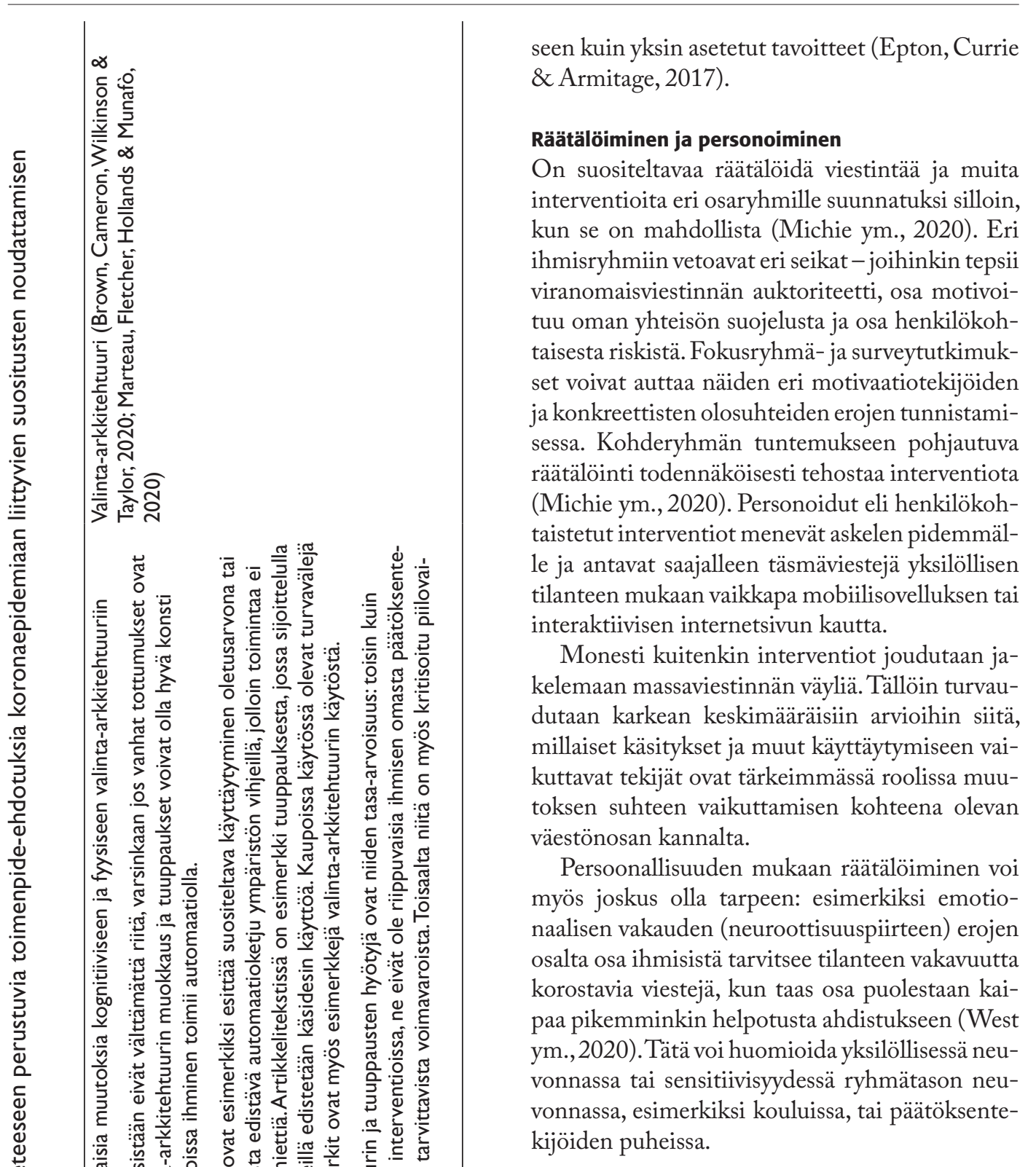

Sosioekonomisen aseman huomioiminen

Psykologisen tason tekijät kytkeytyvät sosioekonomisen tason tekijöihin. Isossa-Britanniassa tehty tutkimus (Atchison ym., 2020) tarkasteli useiden eri demografisten tekijöiden yhteyttä suojautumiseen. Sen mukaan kaikissa väestöryhmissä motivaatio eristäytymiseen ja etäisyyden pitämiseen oli yhtä korkea, mutta käytännön mahdollisuudet eristäytyä olivat merkittävästi huonommat vähätuloisilla, esimerkiksi työn edellyttämien fyysisten kontaktien tai asuntojen 
ahtauden takia. Myös epidemian itsensä on havaittu leviävän helpommin köyhemmissä väestöryhmissä. Väljissä asuinoloissa perheenjäsenten tartunnoilta on helpompi eristäytyä.

Psykologisen tiedon hyödyntäminen interventioiden suunnittelussa ei sulje pois yhteiskunnallisten, rakenteellisten eriarvioisuustekijöiden huomioimista (ks. myös tasa-arvoa koskeva APEASE-arviointikriteeri).

\section{Käyttäytymistieteet käytännön mini- interventioissa}

Emme esittele minkään tietyn käyttäytymismuutosintervention suunnittelua tämän koontiartikkelin puitteissa, mutta hahmottelemme esimerkinomaisesti kaksi mini-interventiota. Käyttäytymistieteitä voisi soveltaa esimerkiksi seuraavilla tavoilla käsihuuhteen käyttämisen ja käsienpesutottumuksen lisäämiseksi.

Valinta-arkkitehtuurin muuttaminen ja tuuppaus käsihuuhteen käyttöön

Apteekissa käsidesiä on sijoitettu jonotusnumeroautomaatin viereen ja ulko-ovelle, mutta havaintojen mukaan sitä käyttää automaatilla vain noin puolet kävijöistä ja ulko-ovella ei juuri kukaan.

Käyttöön voi tuupata esimerkiksi kehittämällä automaattisen toimintaketjun näin: merkitse ovelta tullessa lattiaan jalanjäljet, jotka johtavat jonotusnumeroautomaatille; laita nuoli osoittamaan automaatin nappia ja merkitse nuoli ykkösellä; laita toinen nuoli osoittamaan automaatilta käsidesiin ja merkitse se kakkosella; laita kolmas nuoli osoittamaan ulko-ovella olevaa käsidesiä ja merkitse se kolmosella.

\section{Käsienpesutottumusten muodostaminen}

Tottumusten muodostumista koskevan tämänhetkisen tutkimusnäytön mukaan (Gardner, Rebar \& Lally, 2020) suositeltavat askelet tottumusten muodostamiseksi ovat seuraavat:

Valitse samana toistuva konteksti, jossa teko aina toteutuu, ja liitä siihen teon käynnistävä tilannevihje sekä mieti teosta seuraava palkinto. Esimerkki: aina kun tulen kotiin (konteksti) ja olen ripustanut takin naulakkoon (tilannevihje), menen suoraan vessaan pesemään käteni (teko) ja kuivaan ne hyvin (teko), samalla panen merkille käsien puhtauden ja hyvän tuoksun (palkintona mielihyvä).

Päätä toteuttaa aina sama teko saman kontekstin ja ärsykkeen yhteydessä ja toista tätä viikon ajan. Seuraa edistymistä ja pane merkille poikkeamat.

Avainasioita hyvien konteksti-tilannevihjeteko-ketjujen muodostamisessa: Valitse tilannevihje,joka toistuu riittävän usein. Tilannevihje voi olla jokin ulkoinen tapahtuma tai vaikka sisäinen tila, mutta esimerkiksi kellonajan ei ole havaittu olevan yhtä toimiva ärsyke/vihje laukaisemaan toivottua tekoa.

\section{EMPIIRISEN NÄYTÖN ASTE: MISSÄ VAIHEESSA PSYKOLOGIATIETEEN PERUSTEELLA VOIDAAN ANTAA SUOSITUKSIA?}

Suurta osaa psykologisista teorioista ja erityisesti käyttäytymiseen vaikuttamisen periaatteista ei ole laajamittaisesti testattu korkeatasoisissa tutkimusasetelmissa. Monia tutkimuksia, myös sellaisia, joihin oppikirjoihin sisällytettyjä "lainalaisuuksia" perustuu, on aiheellisesti kritisoitu metodologisista puutteista (ks. esim. Valtonen \& Hankonen, 2019). Lääketieteessä on käytössä evidenssipyramidi, jossa korkeinta ja vahvinta näytön tuottamisen muotoa edustavat metodologialtaan laadukkaat satunnaistetut kokeet. Harvaa tässä annettua toimenpidesuositusta on tällä tavalla testattu ainakaan kriisiviestinnän kontekstissa.

Nämä epävarmuustekijät on hyvä pitää mielessä, kun psykologisen tutkimuksen ja teorian perusteella lähdetään antamaan suosituksia käytäntöön. Emme ole kuitenkaan yhtä pessimistisellä mielellä tästä kuin osa tutkijoista, jotka peräänkuuluttavat hyvinkin varovaista suhtautumista suositusten vetämiseen psykologiatieteen "epäkypsyyden” takia (IJzerman ym., 2020). Mielestämme koronapandemian kaltaisessa akuutissa kriisissä on parempi olla mukana niissä keskusteluissa, joissa ongelmia ratkaistaan, kuin vetäytyä odottamaan täydellisen tutkimusnäytön kertymistä. Akuutissa kriisitilanteessa toimenpiteet kannattaa perustaa luotettavimpaan käytössä olevaan tietoon - sen epävarmuudet tiedostaen. Evidenssipyramidin huipulla ovat satunnaistetut 
kokeet mutta alemmilla portailla tunnistetaan myös kliinisten kokemusten ja tapaustutkimusten arvo. Kyse ei lopulta ole siitä, käytetäänkö psykologiaa toimenpiteiden suunnittelussa. Kyse on siitä - kuten professori John Drury on todennut (Bealing, 7.5.2020) - mitä psykologiaa suunnittelussa käytetään: tutkijoiden tarjoamia tieteellisesti kehitettyjä psykologisia teorioita vai päättäjien omia arkipsykologisia teorioita? Druryn ja kollegoiden (2019) mukaan päättäjien arkipsykologiset teoriat saattavat olla kriisitilanteissa jopa vahingollisia, esimerkiksi kun perusteeton usko massojen taipumukseen panikoida johtaa informaation pimittämiseen. Jos täydellistä tutkimusnäyttöä ei ole, on silti parempi huomioida evidenssipyramidin alemmilta portailta löytyvä tutkimusnäyttö - tai käytännön tai kliininen kokemus - kuin jättää se huomiotta. Valistunut arvaus osuu todennäköisemmin oikeaan kuin sumea arvaus. Ja jos käyttäytymistieteilijät ovat hiljaa, se jää helposti huomiotta.

Samalla tavalla kuin virologit tai lääkärit, käyttäytymistieteiden edustajat voivat myöntää, että vielä emme ymmärrä kohteena olevasta asiasta riittävästi, mutta voimme kuitenkin auttaa ratkaisuehdotusten hahmottelussa parhaan tähän asti kertyneen tiedon ja käytännön kokemuksen pohjalta. Vaikka näyttöpohja vaikuttavista toimenpiteistä on puutteellista, toimenpiteitä joka tapauksessa tehdään. Tieteen kontribuution ei välttämättä tarvitsekaan olla varmoja lupauksia ratkaisukeinoista. Monesti päätöksentekijät ja käytännön toimijat arvostavat jo pelkästään käsitteellisiä työkaluja ja viitekehyksiä,joilla käyttäytymistieteilijät voivat auttaa hahmottamaan ongelmaa jäsentyneemmin. Kuten Einstein (1936) on todennut, tieteessä kyse on arkiajattelun hiomisesta ja täsmentämisestä. Tieteellisen ja arkitiedon erottaa lopulta vain se, että ensin mainitussa tiedon tuottamiseen käytetään pitkälle hiottuja ja kollektiivisia tiedon tuottamisen tapoja, joilla pyritään varmistamaan saavutetun ymmärryksen luotettavuus (Martela, 2015). Näin ollen käyttäytymistieteiden käsitteelliset työkalut auttavat jäsentämään kehittyneitäkin päätöksenteossa käytössä olevia arkiteorioita sekä myös retroaktiivisesti analysoimaan olemassa olevia toimenpiteitä (ks. esim. Seppälä, Hankonen, Korkiakangas \& Ruusuvuori, 2017).
Tieteen tarkoitus on myöskin tuottaa parhaaseen käytettävissä olevaan tietoon perustuvia hypoteeseja ja opastaa niiden testaamisessa niin, että näyttöä kertyisi tulevaisuutta varten. Meidän ei toki tarvitse jäädä vain pyramidin "asiantuntijanäkemyksen" näytön tasolle, vaan tulevaisuudessa voimme korkeatasoisin tutkimusasetelmin kerryttää näyttöä.

On kuitenkin jatkossa aiheellista pitää entistä paremmin mielessä tieto siitä, millainen näyttö on erilaisten politiikkasuositusten takana - mutta miten toteuttaa tätä käytännössä? Ruggeri kollegoineen (2020) onkin myös ehdottanut käyttöön uutta viitekehystä, jonka avulla voitaisiin asettaa standardit näytölle, jota käytetään päätöksenteossa. Viitekehyksessä validoinnin tasoja on viisi, joista alin on teoreettinen (heikoin taso (argumentti tai mahdollinen selitys muotoiltu) ja korkein on "impakti" (efekti on luotettavasti todennettu ja replikoitu "todellisen elämän" kontekstissa, ja sillä on todellista merkitystä käytännössä). Kirjoittajat ehdottavat, että järjestelmää voitaisiin soveltaa mihin tahansa julkaistuun työhön (esim. alaviitteinä) - näin näytön taso ja vahvuus olisi jatkuvasti näkyvillä. Nähtäväksi jää, miten tämä vielä tällä hetkellä julkaisematon viitekehys tai vastaavat luokitusjärjestelmät tulevat vakiintumaan tieteenalamme käyttöön.

\section{LOPUKSI}

Käyttäytymistieteilijöitä toivotaan apuun meneillään olevaan koronavirusepidemiaan sisältyvien käyttäytymiseen liittyvien ongelmien ratkaisemisessa. Ja näitä pulmia riittää, nopealla tahdil1a. Mutta mikä on osaamisessamme käytännön ja teorian suhde: antaako suomalainen koulutus psykologian ja sosiaalipsykologian maisteriohjelmissa valmiuksia suunnitella tieteelliseen näkemykseen perustuen käyttäytymisen muutostoimenpiteitä tai neuvoa ja tukea muiden alojen virkamiehiä käyttäytymistiedon hyödyntämisessä? Psykologian ja sosiaalipsykologian koulutusohjelmissa on viime vuosina otettu askelia kohti soveltamista harjoittavia kursseja ja vahvistettu opiskelijoiden valmiuksia analysoida käytännön käyttäytymismuutosongelmia ongelmalähtöisesti (ei teoria edellä) sekä etsiä niihin näyttöön 
ja teorioihin tukeutuvia ratkaisuja. Artikkelin ensimmäinen osa osoittaa, että vaikkei valmiita vastauksia ole, käyttäytymismuutostieteelliset systemaattisen interventiosuunnittelun menetelmät ovat käyttökelpoinen anti,joita taitoja yhteiskunnassa laajalti tarvitaan.

Toisaalta artikkelin toisessa osassa kuvatunlaiselle substanssiosaamisellekin on laaja kysyntä: Koska sosiaalipsykologeilla on syvällistä tietoa inhimillisen käyttäytymisen yksilöllisistä ja interpersoonallisista prosesseista (Ruiter, Massar, Vugt \& Kok, 2013), heillä voisi olla tärkeä rooli monenlaisten yhteiskunnallisten ongelmien ratkaisemisessa (Hankonen, 2012; Hankonen \& Renko, 2019). Tämä edellyttää soveltavan sosiaalipsykologian sisältyvän koulutusohjelmiin (Ruiter ym., 2013).

Lopuksi on todettava, että psykologia ja sosiaalipsykologia eivät ole ainoita käyttäytymiseen ja käyttäytymismuutoksen tieteelliseen tarkasteluun kontribuoivia tieteenaloja, vaan myös kognitiotiede, sosiologia, antropologia, kansantalous-

\section{Lähteet}

Abraham, C., Kok, G., Schaalma, H. P. \& Luszczynska, A. (2011). Health promotion. Teoksessa P. R. Martin, F. M. Cheung, M. C. Knowles, M. Kyrios, L. Littlefield, J. B. Overmier \& J. M. Pieto (toim.), LAAP handbook of applied psychology (s. 81-111). Wiley-Blackwell IAAP Handbook of Applied Psychology. Wiley-Blackwell.

Atchison, C. J., Bowman, L., Vrinten, C., Redd, R., Pristera, P., Eaton, J. W. \& Ward, H. (2020). Perceptions and behavioural responses of the general public during the COVID-19 pandemic: A cross-sectional survey of UK adults. MedRxiv. doi:10.1101/2020.04.01.20050039.

Bartholomew Eldredge, L. K., Markham, C. M., Ruiter, R. A. C., Kok, G. \& Parcel, G. S. (2016). Planning health promotion programs: An intervention mapping approach. Hoboken, NJ: John Wiley \& Sons.

Bealing, J. (7.5.2020). Why collective behaviour will get us through the Covid-19 pandemic - Interview with professor John Drury. University of Sussex. Haettu osoitteesta https://student.sussex.ac.uk/news/article/51930-whycollective-behaviour-will-get-us-through-the-covid-19pandemic.

Bish, A. \& Michie, S. (2010). Demographic and attitudinal determinants of protective behaviours during a pandemic: tiede, politiikan tutkimus, viestintä ja muut käyttäytymis- ja yhteiskuntatieteet tarjoavat tärkeitä ja täydentäviä näkökulmia (Hankonen \& Renko, 2019; Van Bavel ym., 2020). Monitieteinen lähestymistapa auttaa ymmärtämään kompleksisia ongelmia. Myöskään pelkästä norsunluutornista maailmaa ei muuteta. Ihmisiä itseään tulee osallistaa toimenpiteiden suunnittelemiseen ja kehittämiseen. Parhaimmillaan käyttäytymisen muutoksen suunnittelu hyödyntää sekä useiden tieteenalojen tietoa että ihmisten omaa arkitietoa, ja tässä kokonaisuudessa psykologisella ja sosiaalipsykologisella tutkimuksella on oma merkittävä roolinsa.

Artikkeli on saatu toimitukseen 15.5.2020 ja hyväksytty julkaistavaksi 14.8.2020.

\section{Kiitokset}

Kiitämme VTM Minttu Palsolaa avusta artikkelin kirjoitusasun viimeistelyssä.

A review. British Journal of Health Psychology, 15, 797-824 doi:10.1348/135910710x485826.

Bonell, C., Michie, S., Reicher, S., West, R., Bear, L., Yardley, L., ... \& Rubin, G. J. (2020). Harnessing behavioural science in public health campaigns to maintain 'social distancing' in response to the COVID-19 pandemic: Key principles. J Epidemiol Community Health. doi:10.1136/ jech-2020-214290.

Brown, P. M., Cameron, L. D., Wilkinson, M. \& Taylor, D. (2020). Economic and behavioral economic interventions. Teoksessa M. S. Hagger, L. Cameron, K. Hamilton, N. Hankonen \& T. Lintunen (toim.), The handbook of behaviour change (s. 617-631). Cambridge University Press.

Carter, H., Drury, J., Rubin, G. J., Williams, R. \& Amlôt, R. (2015). Applying crowd psychology to develop recommendations for the management of mass decontamination. Health Secur, 13(1), 45-53. doi:10.1089/hs.2014.0061.

Carver, C. S. \& Scheier,M. F. (1982). Control theory: A useful conceptual framework for personality-social, clinical, and health psychology. Psychological Bulletin, 92(1), 111-135.

Czerniewska, A. \& White, S. (2020). Hygiene programming during outbreaks: A qualitative case study of the humanitarian response during the Ebola outbreak in Liberia. 
BMC Public Health, 20, 154. doi:10.1186/s12889-0208240-9.

Clark, F., Sanders, K., Carlson, M., Blanche, E. \& Jackson, J. (2007). Synthesis of habit theory. OTJR: Occupation, Participation and Health, 27, 7S-23S.

Drury, J. (2018). The role of social identity processes in mass emergency behaviour: An integrative review. European Review of Social Psychology, 29(1), 38-81.

Drury, J., Carter, H., Cocking, C., Ntontis, E., Tekin Guven, S. \& Amlôt, R. (2019). Facilitating collective psychosocial resilience in the public in emergencies: Twelve recommendations based on the social identity approach. Frontiers in Public Health, 7. doi:10.3389/fpubh.2019.00141.

Einstein, A. (1936). Physics and reality. Journal of the Franklin Institute, 221(3), 349-382. doi:10.1016/S00160032(36)91047-5.

Epton, T., Currie, S. \& Armitage, C. J. (2017). Unique effects of setting goals on behavior change: Systematic review and meta-analysis. Journal of Consulting and Clinical Psychology, 85(12), 1182-1198. doi:10.1037/ccp0000260.

Everett, J. A. C., Colombatto, C., Chituc, V., Brady, W. J. \& Crockett, M. (2020). The effectiveness of moral messages on public health behavioral intentions during the COVID-19 pandemic. PsyArXiv Preprints. doi:10.31234/osf. io/9yqs8.

Fishbein, M. \& Ajzen, I. (2011). Predicting and changing behavior: The reasoned action approach. New York, NY: Taylor $\&$ Francis.

Gallagher, K. M. \& Updegraff, J. A. (2012). Health message framing effects on attitudes, intentions, and behavior: A meta-analytic review. Ann Behav Med, 43(1), 101-116. doi:10.1007/s12160-011-9308-7.

Gamma, A. E., Slekiene, J., von Medeazza, G., Asplund, F., Cardoso, P. \& Mosler, H.-J. (2017). Contextual and psychosocial factors predicting Ebola prevention behaviours using the RANAS approach to behaviour change in Guinea-Bissau. BMC Public Health, 17, 446. doi:10.1186/ s12889-017-4360-2.

Gardner, B., Rebar, A. L. \& Lally, P. (2020). Habit interventions. Teoksessa M. S. Hagger, L. Cameron, K. Hamilton, N. Hankonen \& T. Lintunen (toim.), The handbook of behaviour change (s. 599-616). Cambridge University Press.

Gillison, F. B., Rouse, P., Standage, M., Sebire, S. J. \& Ryan, R. M. (2019). A meta-analysis of techniques to promote motivation for health behaviour change from a self-determination theory perspective. Health Psychology Review, 13(1), 110-130.

Grant, A. M. \& Hofmann, D. A. (2011). It's not all about me: Motivating hand hygiene among health care profession- als by focusing on patients. Psychological Science, 22(12), 1494-1499.

Hagger, M., Cameron, L., Hamilton, K., Hankonen, N. \& Lintunen, T. (toim.) (2020). The handbook of behaviour change. Cambridge University Press.

Hagger, M. S., Luszczynska, A., de Wit, J., Benyamini, Y., Burkert, S., Chamberland, P., ... \& Gollwitzer, P. M. (2016). Planning and implementation intention interventions in health psychology: Consensus statement and recommendations. Psychology \& Health, 31(7), 814-839. doi:10.1080/08870446.2016.1146719.

Hagger, M. S. \& Weed, M. (2019). DEBATE: Do interventions based on behavioral theory work in the real world? Int J Behav Nutr Phys Act, 16, 36. doi:10.1186/s12966019-0795-4.

Hankonen, N. (2012). Mitä sosiaalipsykologia voisi olla? Sosiaalipsykologia vaikuttamisen tieteenä, vaikuttajana yhteiskunnassa. Teoksessa A.-L. Lahikainen, E. Suoninen, I. Järventie \& M. Salonen (toim.), Sosiaalipsykologian sukupolvet (s. 243-260). Tampere: Vastapaino.

Hankonen, N. (2017). Miten motivoida kohti hyvinvointia? Käyttäytymismuutosinterventiot terveyden edistämiseksi. Teoksessa K. Salmela-Aro \& J.-E. Nurmi (toim.), Mikä meitä liikuttaa? Motivaatiopsykologian perusteet (s. 202221). Juva: PS-kustannus.

Hankonen, N. \& Hardeman, W. (2020). Developing behaviour change interventions. Teoksessa M. S. Hagger, L. Cameron, K. Hamilton, N. Hankonen \& T. Lintunen (toim.), The handbook of behavior change (s. 300-317). Cambridge University Press.

Hankonen, N. \& Renko, E. (2019). Psykologia ratkaisemassa maailman hankalia ongelmia. Futura, 38(2), 11-18.

Heino, M. T. J., Knittle, K., Noone, C., Hasselman, F. \& Hankonen, N. (2020). Studying behaviour change mechanisms under complexity. PsyArxiv. doi:10.31234/osf.io/fxgw4.

IJzerman, H., Lewis, N. A., jr, Weinstein, N., DeBruine, L. M., Ritchie, S. J., Vazire, S., ... \& Przybylski, A. K. (2020). Psychological science is not yet a crisis-ready discipline. PsyArXiv Preprints. doi:10.31234/osf.io/whds4.

Jordan, J., Yoeli, E. \& Rand, D. (2020). Don't get it or don't spread it? Comparing self-interested versus prosocially framed COVID-19 prevention messaging. PsyArXiv Preprints. doi:10.31234/osf.io/yuq7x.

Kahneman, D. \& Miller, D. T. (1986). Norm theory: Comparing reality to its alternatives. Psychol Rev, 93, 136-153.

Kangasniemi, J. (4.4.2020). Miksi osa ihmisistä ei noudata rajoituksia, vaikka ne ovat kaikkien tiedossa? Sosiaalipsykologi listaa kahdeksan psykologista harhaa, joihin kaikki meistä ovat vaarassa sortua. Helsingin Sanomat. 
Haettu osoitteesta https://www.hs.fi/hyvinvointi/art2000006463248.html.

Kwasnicka, D., Dombrowski, S. U., White, M. \& Sniehotta, F. F. (2016). Theoretical explanations for maintenance of behaviour change: A systematic review of behaviour theories. Health Psychology Review, 10(3), 277-296.

Kwasnicka, D., Presseau, J., White, M. \& Sniehotta, F. F. (2013). Does planning how to cope with anticipated barriers facilitate health-related behaviour change? A systematic review. Health Psychology Review, 7(2), 129-145.

Legault, L., Gutsell,J. N. \& Inzlicht, M. (2011). Ironic effects of antiprejudice messages: How motivational interventions can reduce (butalso increase) prejudice. Psychological Science, 22(12), 1472-1477. doi:10.1177/0956797611427918.

Linnansaari, A. \& Hankonen, N. (2019). Terveyskäyttäytymiseen vaikuttaminen: interventioiden suunnittelun ja arvioinnin pääpiirteitä. Teoksessa S. Sinikallio (toim.), Terveyden psykologia (s. 89-134). Jyväskylä: PS-kustannus.

Lunn, P., Belton, C., Lavin, C., McGowan, F., Timmons, S. \& Robertson, D. (2020). Using behavioural science to help fight the corona virus. Economic and Social Research Institute. Haettu osoitteesta https://www.esri.ie/publications/using-behavioural-science-to-help-fight-the-coronavirus.

Mackie, D. M., Worth, L. T. \& Asuncion, A. G. (1990). Processing of persuasive in-group messages. Journal of Personality and Social Psychology, 58(5), 812-822.

Marteau, T. M., Fletcher, P. C., Hollands, G. J. \& Munafo,, M. R. (2020). Changing behaviour by changing environments. Teoksessa M. S. Hagger, L. Cameron, K. Hamilton, N. Hankonen \& T. Lintunen (toim.), The handbook of behaviour change (s. 193-207). Cambridge University Press.

Marteau, T. M., Hollands, G. J. \& Fletcher, P. C. (2012). Changing human behavior to prevent disease: The importance of targeting automatic processes. Science, 337(6101), 1492-1495. doi:10.1126/science.1226918.

Martela, F. (2015). Fallible inquiry with ethical ends-inview: A pragmatist philosophy of science for organizational research. Organization Studies, 36(4), 537-563. doi:10.1177/0170840614559257.

Michie, S.,Atkins, L. \&West, R. (2014). The Behaviour Change Wheel:A guide to designing interventions. Great Britain: Silverback Publishing.

Michie, S. \& Prestwich, A. (2010). Are interventions theory-based? Development of a theory coding scheme. Health Psychology, 29(1), 1-8. doi:10.1037/a0016939.

Michie, S., van Stralen, M. M. \&West, R. (2011). The Behaviour Change Wheel: A new method for characterising and designing behaviour change interventions. Implementation Science, 6(1), 42. doi:10.1186/1748-5908-6-42.

Michie, S., West, R., Campbell, R., Brown, J. \& Gainforth, H. (2014). ABC of behaviour change theories. Great Britain: Silverback Publishing.

Michie, S., West, R., Rogers, M. B., Bonell, C., Rubin, J. \& Amlôt, R. (2020). Reducing SARS-CoV-2 transmission in the UK: A behavioural science approach to identifying options for increasing adherence to social distancing and shielding vulnerable people. British Journal of Health Psychology. doi:10.1111/bjhp.12428.

Ntoumanis, N., Ng,J. Y. Y., Prestwich, A., Quested, E., Hancox, J. E., Thøgersen-Ntoumani, C., ... \& Williams, G. C. (2020). A meta-analysis of self-determination theory-informed intervention studies in the health domain: Effects on motivation, health behavior, physical, and psychological health. Health Psychology Review, 1-31. doi:10.1080/1743 7199.2020.1718529.

O'Cathain, A., Croot, L., Sworn, K., Duncan, E., Rousseau, N., Turner, K., ... \& Hoddinott, P. (2019). Taxonomy of approaches to developing interventions to improve health: A systematic methods overview. Pilot and Feasibility Studies, 5(1), 41. doi:10.1186/s40814-019-0425-6.

Oldenburg, B., Absetz, P. \& Chan C. (2010). Behavioral interventions for prevention and management of chronic disease. Teoksessa A. Steptoe (toim.), Handbook of behavioral medicine: Methods and applications (s. 969-988). New York: Springer.

Reynolds, J. P., Stautz, K., Pilling, M., van der Linden, S. \& Marteau, T. M. (2020). Communicating the effectiveness and ineffectiveness of government policies and their impact on public support: A systematic review with meta-analysis. R. Soc. open sci., 7, 190522. doi:10.1098/ rsos.190522.

Ruggeri, K., van der Linden, S., Wang, Y. C., Papa, F., Riesch, J. \& Green, J. (2020). Standards for evidence in policy decision-making. Nature Research Social and Behavioural Sciences, 399005. Haettu osoitteesta go.nature.com/2zdTQIs.

Ruiter, R., Crutzen, R., de Leeuw, E. \& Kok, G. (2020). Changing behavior using theories at the interpersonal, organizational, community and societal levels. Teoksessa M. S. Hagger, L. Cameron, K. Hamilton, N. Hankonen \&T. Lintunen (toim.), The handbook of behaviour change (s. 251-265). Cambridge University Press.

Ruiter, R., Massar, K., Vugt, M. \& Kok, G. (2013). Applying social psychology to understanding social problems. Teoksessa A. Golec de Zavala \& A. Cichocka (toim.), Social psychology of social problems. Palgrave MacMillan. 
Ryan, R. M. \& Deci, E. L. (2017). Self-determination theory: Basic psychological needs in motivation, development, and wellness. New York, NY: Guilford Press.

Scientific Pandemic Influenza behaviour Advisory Committee (SPI-B) (2020a). Insights on self-isolation and household isolation. Haettu 12.5.2020 osoitteesta https://post. parliament.uk/analysis/covid-19-insights-from-behavioural-science/.

Scientific Pandemic Influenza behaviour Advisory Committee (SPI-B) (2020b). The role of behavioural science in the coronavirus outbreak.

Sekhon,M.,Cartwright,M. \& Francis,J.(2017).Acceptability of healthcare interventions: An overview of reviews and development of a theoretical framework. BMCHealth Services Research, 17(1), 88. doi:10.1186/s12913-017-2031-8.

Seppälä, T., Hankonen, N., Korkiakangas, E. \& Ruusuvuori, J. (2017). National policies for the promotion of physical activity and healthy nutrition in the workplace context: A Behaviour Change Wheel guided content analysis of policy papers in Finland. BMC Public Health, 18(1), 87. doi:10.1186/s12889-017-4574-3.

The Independent Scientific Advisory Group for Emergencies (SAGE) (2020). COVID-19: What are the options for the UK? Recommendations for government based on an open and transparent examination of the scientific evidence. Haettu 12.5.2020 osoitteesta http://www.independentsage.org/wp-content/uploads/2020/05/The-Independent-SAGE-Report.pdf.

Tversky, A. \& Kahneman, D. (1992). Advances in prospect theory: Cumulative representation of uncertainty. Journal of Risk and Uncertainty, 5, 297-323.

Valtonen, J. \& Hankonen, N. (2019). Mitä toistettavuuskriisistä pitäisi ajatella? Psykologia, 54(6), 433-439.
Van Bavel, J. J., Baicker, K., Boggio, P., Capraro, V., Cichocka, A., Crockett, M., ... \& Willer, R. (2020). Using social and behavioural science to support COVID-19 pandemic response. doi:10.31234/osf.io/y38m9.

Vansteenkiste, M., Soenens, B., Van Petegem, S. \& Duriez, B. (2014). Longitudinal associations between adolescent perceived degree and style of parental prohibition and internalization and defiance. Developmental Psychology, 50(1), 229-236.

Webb, T. L., Joseph, J., Yardley, L. \& Michie, S. (2010). Using the internet to promote health behavior change: A systematic review and meta-analysis of the impact of theoretical basis, use of behavior change techniques, and mode of delivery on efficacy.J Med Internet Res, 12(1), e4. doi:10.2196/jmir.1376.

Weinstein, N., Vansteenkiste, M. \& Paulmann, S. (2020). Don't you say it that way! Experimental evidence that controlling voices elicit defiance. Journal of Experimental Social Psychology, 88, 103949. doi:10.1016/j. jesp.2019.103949.

West, R., Michie, S., Rubin, G. J. \& Amlôt, R. (2020). Applying principles of behaviour change to reduce SARSCoV-2 transmission. Nature Human Behaviour, 4, 451459. doi:10.1038/s41562-020-0887-9.

WHO (2020). Statement - Behavioural insights are valuable to inform the planning of appropriate pandemic response measures. 15 May 2020, Statement to the press by Dr Hans Henri P. Kluge, WHO Regional Director for Europe. Haettu 22.6.2020 osoitteesta https://www.euro. who.int/en/media-centre/sections/statements/2020/ statement-behavioural-insights-are-valuable-to-inform-the-planning-of-appropriate-pandemic-response-measures. 


\section{HANKONEN, N., ABSETZ, P., \& MARTELA, $F$.}

\section{How to increase adherence to recommendations to prevent the spread of epidemics: Contributions of the behavioural sciences}

Psykologia 55 316-336 Tallinn ISSN 0355-1067 (printed) ISSN 2670-322X (online)

Preventing the spread of the new coronavirus requires many behavioural changes such as social distancing and regular hand washing. It is impossible to monitor the adherence to many of these guidelines and some might be in place for long periods of time. Accordingly, the effectiveness of the preventive measures is, to a large degree, dependent on people's voluntary compliance. Within psychology in general, and social psychology in particular, there is a long tradition of research on how to influence people's attitudes, motivations, and behaviour. There are also systematic frameworks for the development of effective behavioural interventions. The aim of the present article is 1 ) to demonstrate the usefulness of analysing behaviour and systematic intervention development in designing measures to help stop the spread of the epidemic, and 2) offer a number of concrete guidelines for such policies based on theories and evidence from the behavioural sciences. Behavioural sciences can be utilised in, for example, designing illustrative and motivating communication materials and ways of communicating, designing interventions through which people could consciously develop new routines for themselves, and tailoring the approaches to various subgroups. In the best case, policies activate people's social identities and support their autonomous motivation, thus awakening a strong personal commitment to the required behaviour. The article is based on a review of literature reviews that makes use of both the past evidence base as well as recent scientific articles on how to utilise behavioural knowledge to prevent the spread of sars$\mathrm{CoV}-2$ virus.

\section{Keywords:}

coronavirus, sars- $\mathrm{CoV}-2$, covid-19, policy, public administration, civil servants, behaviour change, health promotion, disease prevention

\section{Authors:}

Nelli Hankonen, $\mathrm{PhD}$, title of docent, associate professor of social psychology, Faculty of Social Sciences, P.O. Box 54,

FI-00014 University of

Helsinki,

Finland, nelli.hankonen@helsinki.fi

Pilvikki Absetz, DPsych, title of docent, Tampere University, Finland

Frank Martela, $\mathrm{PhD}$, title of docent, postdoctoral researcher, Aalto University, Finland 


\section{PILVIKKI ABSETZ, PsT}

terveyden edistämisen dosentti

Tampereen yliopisto

\section{KATARINA ALANKO, PsT}

docent, universitetslärare

Fakulteten för humaniora, psykologi och teologi

Åbo Akademi

\section{OUTI ALANKO, PsL}

psykologi

Turun yliopistollinen keskussairaala

\section{TOMMI ALANKO, FT}

dosentti, johtaja

Työterveyslaitos

\section{ULLA ANTTILA, ST, VTM}

asiantuntija

Psyykkisen hyvinvoinnin keskus Komppi

vapaa tietokirjoittaja

psykoterapeuttikoulutettava

Itä-Suomen yliopisto ja

Lyhytterapiainstituutti

\section{ISABELLA ARPONEN, PsK}

Fakulteten för humaniora, psykologi och teologi

Åbo Akademi

\section{NELLI HANKONEN, VTT}

sosiaalipsykologian apulaisprofessori

Valtiotieteellinen tiedekunta

Helsingin yliopisto

\section{PAULIINA MATTILA-HOLAPPA, PsT}

vanhempi asiantuntija

Työterveyslaitos

\section{JUHA HOLMA, PsT}

psykoterapeutti, professori

Psykologian laitos

Jyväskylän yliopisto

\section{MIA HUOLMAN, PsM}

lasten ja nuorten erikoispsykologi

Hämeenlinnan lastenpsykiatrian yksikkö

\section{PAUL KNEKT, THT}

dosentti, tutkimuspäällikkö

Terveyden ja hyvinvoinnin laitos

\section{EMMA KORHONEN, PsM}

vieraileva tutkija

Terveyden ja hyvinvoinnin laitos

OLAVI LINDFORS, PsT

dosentti, kehittämispäällikkö

Terveyden ja hyvinvoinnin laitos;

Psykologian ja logopedian laitos

Lääketieteellinen tiedekunta

Helsingin yliopisto

\section{FRANK MARTELA, VTT, FT}

tutkijatohtori

Tuotantotalouden laitos

Aalto-yliopisto;

hyvinvoinnin psykologian dosentti

Tampereen yliopisto

\section{TIINA-MARI MONNI, DI}

tuotepäällikkö

Työterveyslaitos

\section{PIA PERTTULA, TkT}

vanhempi tutkija

Työterveyslaitos

\section{VIRPI RUOHOMÄKI, FT}

vanhempi tutkija

Työterveyslaitos

\section{JUHA SALMITAIVAL, PsT}

akatemiatutkija

Aalto-yliopisto;

erikoistuva neuropsykologi

\section{SALLA TOPPINEN-TANNER, PsT}

johtaja

Työterveyslaitos

SEPPO TUOMIVAARA, PsT

erikoistutkija

Työterveyslaitos 